Original research article

\title{
When energy policy meets free-market capitalists: The moderating influence of worldviews on risk perception and renewable energy investment decisions
}

\author{
Sylviane Chassot ${ }^{\mathrm{a}, *}$, Nina Hampl ${ }^{\mathrm{b}}$, Rolf Wüstenhagen ${ }^{\mathrm{a}}$ \\ a Institute for Economy and the Environment (IWÖ-HSG), University of St.Gallen, Switzerland \\ ${ }^{\mathrm{b}}$ Institute for Strategic Management, Vienna University of Economics and Business, Austria
}

\section{A R T I C L E I N F O}

\section{Article history:}

Received 5 January 2014

Received in revised form 29 July 2014

Accepted 31 July 2014

\section{Keywords:}

Renewable energy

Regulatory risk

Worldview

Venture capital

\begin{abstract}
A B S T R A C T
Whether or not targets to increase the share of renewable energy will eventually be met critically hinges upon the effectiveness of policies to mobilize private investment. However, just as energy policy can create opportunities, it can also create risk. This paper adds to a growing stream of literature at the intersection of energy research and social sciences that empirically investigates investor perceptions of regulatory risk, and their influence on investment decision-making. Based on choice experiments with 29 venture capital investors from Europe and the United States conducting 1064 investment decisions, we show that high levels of regulatory risk have a negative effect on the likelihood to invest in renewable energy. Furthermore, we find that investors' worldviews moderate the impact of perceived regulatory risk: respondents who expose strongly individualistic "free-market" worldviews are less likely to invest in renewable energy ventures with high regulatory exposure than other investors.
\end{abstract}

(c) 2014 Elsevier Ltd. All rights reserved.

\section{Introduction}

An extrapolation of current energy trends into the future is not sustainable. A culmination of increasing concerns about climate change, the nuclear accident in Fukushima, and discussions on energy security in a world with growing energy demand have led to a call for increasing the share of renewable energy. Building up a cleaner energy infrastructure requires significant investment. UNEP [1] reports that total global investment in renewable energy was $\$ 214$ billion in 2013 , which is a decrease of $14 \%$ compared to 2012. The main reasons for the decline in investment indicated in this report are twofold: (1) a sharp decline in technology cost, making investments in a given amount of renewable energy capacity cheaper than before, but also (2) the instability in policy support for renewable energy in some key markets in Europe and the United States. While the former is a positive development, the latter raises a serious concern with regard to achieving ambitious policy targets.

\footnotetext{
* Corresponding author at: Institute for Economy and the Environment (IWÖHSG), University of St.Gallen, Tigerbergstrasse 2, 9000 St.Gallen, Switzerland. Tel.: +41 71224 2584; mobile: +41 764730965 .

E-mail addresses: sylviane.chassot@gmail.com (S. Chassot), nina.hampl@wu.ac.at (N. Hampl), rolf.wuestenhagen@unisg.ch (R. Wüstenhagen).
}

The International Energy Agency estimates that \$26 trillion need to be invested in energy infrastructure by 2030 in the New Policies Scenario, and that this number increases to $\$ 36$ trillion in the 450 -Scenario, which has the goal of stabilizing the atmosphere at below $2{ }^{\circ} \mathrm{C}$ temperature change [2]. Thus, government policies to promote renewable energy need to be designed in order to spur the required levels of investment. The absence of such investmentgrade policies [3] leads not just to a lack of capital flowing into renewable energy projects, but to continued allocation of capital to conventional sources of energy.

At least two factors have been offered in the energy policy and economics literature to explain the puzzling gap between renewable energy targets and actual levels of investment. First, recent research has pointed to the importance of regulatory risk ${ }^{1}$ [4-10] - mirroring the UNEP findings [1]. While policy makers tend to assume that political incentives create opportunities for renewable energy investors, those policies might actually be viewed as a possible source of risk by investors, leading to disappointing levels of capital flowing into the sector. Second, recent work inspired by behavioural economics suggests that a purely rational risk-return

\footnotetext{
1 We define regulatory risk as "the risk that regulatory agencies will change policy decisions" [4, p. 654]. In this paper, we use regulatory and policy risk as synonyms.
} 
perspective may fall short of explaining the observed investment behaviour and how it is influenced by energy policy. Real-world investor decision-making in the energy industry seems to be more characterized by bounded rationality [11] leading to path dependence and carbon lock-in [12].

Despite its importance, this bounded rationality view on the role of energy policy and regulatory risk in renewable energy investment is still an under-researched field. Our paper responds to recent calls for more research in this area [13-15]. Focusing on one particular type of investor, venture capitalists, we investigate a specific "behavioural" effect, namely whether investors' general worldview influences their level of risk perception with respect to regulatory risk, and thus negatively influences investment in renewable energy. Albeit venture capitalists typically do not directly invest in power generation facilities, they provide capital to technology start-ups, who in turn rely on a favourable investment environment in the downstream sector to find demand for their products [16]. Thus, venture capitalists are important gatekeepers for new energy technology, which will then eventually be applied in power generation projects, financed by e.g. institutional investors and banks. Uncertainty related to policy support in the asset finance sector also has an important indirect impact on the sentiment in public markets, which provide growth capital to renewable companies. Venture capitalists that typically exit investments through initial public offerings (IPOs) are thus also sensitive to the overall investment climate in this financial sector. The focus on venture capitalists therefore provides an interesting perspective on energy policy from the upstream and innovation-focused side of the financing continuum. Additionally, understanding venture capitalists' investment decision-making is particularly in demand, as recent figures show that renewable energy investment in the venture capital/private equity sector dropped by $46 \%$ from 2012 to 2013 to levels observed eight years ago [1].

With empirical evidence from choice experiments with 29 venture capitalists from the United States and Europe conducting 1064 experimental investment decisions, we address the following research question: to what extent is the impact of regulatory risk on the decision to invest in renewable energy moderated by investors' worldviews? Our results show that high exposure to regulatory risk has a negative influence on investment decisions in renewable energy. We further provide empirical evidence that investors' worldviews moderate the relationship between regulatory risk and the decision to invest in renewable energy. Investors with an individualistic ("free-market") worldview perceive risks induced by high regulatory exposure more pronounced than other investors.

\section{Literature review}

\subsection{Policy makers versus investors - two perspectives on energy policy}

A general assumption behind the introduction of renewable energy policies is that investors are more likely to invest in renewable energies in the presence of such policies than they would be in their absence. For example, in the case of feed-in tariffs or investment incentives, policies are designed to provide attractive returns to renewable energy investors. Policy makers tend to pay less attention to the other side of the equation, i.e. the implications of regulatory risk on investments (cf. Fig. 1).

Investors, on the other hand, may have very different views on energy policy. Rather than seeing renewable energy policies as a source of opportunity - as assumed and intended by policy makers - they might interpret them as a source of risk. This alternative view

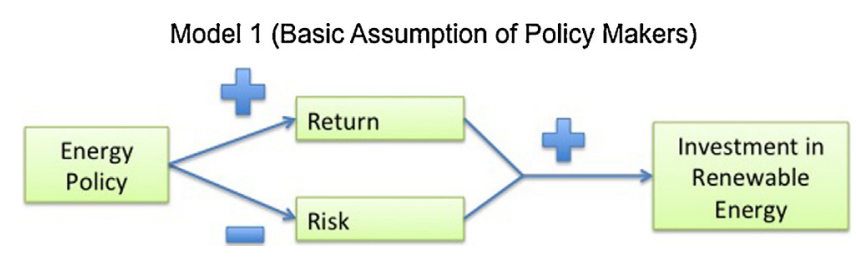

Fig. 1. A simple model of how policies influence renewable energy investment. Adapted from Wüstenhagen and Menichetti [14].

of the policy-investment nexus has been presented as a possible explanation for puzzling findings about renewable energy policy effectiveness [10]. For example, it has been shown that countries with seemingly similar policy frameworks had widely differing outcomes in terms of the amount of new capacity installed [17], and the "price of policy risk" [6] could be a central factor in explaining observed differences.

Energy policy encompasses a rich toolbox of different instruments. In addition to remuneration schemes such as feed-in tariffs or investment subsidies (economic factors), energy policy frameworks are also characterized by so-called non-economic factors such as grid access, legal security and duration of administrative processes [6,7]. Several studies have investigated the impact of economic and non-economic policy aspects on investment decisions by various types of investors $[6-8,18,19]$. Studies that investigate the attractiveness of different policy schemes show that feed-in tariffs are the most appealing financial support scheme from the investors' point of view [16]. Feed-in tariffs decrease the price risk for electricity output and have thus emerged as one of the most effective and most prominent energy policy instruments to promote investments in renewable energies. However, if different policy aspects are jointly investigated, studies show that for investment decisions the relative importance of non-economic policy factors such as the administrative process duration or the risk of negative policy changes (regulatory or policy risk) is higher than the level of total remuneration and the type of policy scheme [6,7].

In this perspective, well-designed policies decrease (perceived) regulatory risk in investment decisions, which in turn has a positive influence on renewable energy project developers' cost of capital $[20,21]$ as it lowers the risk premium [6]. The variations in the risk level that different renewable energy policy frameworks imply are an important indicator for investments - and as a consequence for future installed capacity and policy effectiveness in the longer term [14]. Thus, compared to the policy maker's point of view on the relation between renewable energy policies and investment, the investor's perspective actually seems to place a higher emphasis on risk aspects, cancelling out some or all of the intended positive effect of policies (cf. Fig. 2).

\subsection{Venture capital investment in renewable energy}

A variety of investors is involved in financing renewable energy, ranging from venture capitalists investing in early-stage technology firms to project financiers engaging in the later stages of the innovation cycle, i.e. deployment. While later stage investment

\section{Model 2 (Basic Assumption of Investors)}

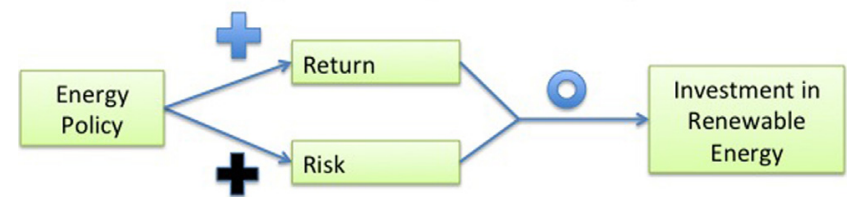

Fig. 2. An alternative model of how policies influence renewable energy investment. Adapted from Wüstenhagen and Menichetti [14]. 
typically appears in larger quantities, venture capital has been shown to be a crucial element of the commercialization process of a range of innovative technologies [22,23], and has recently gained prominence in clean energy. Since 2004, one fifth of investments in clean energy technology development has come from venture capitalists [1]. Venture capital can be defined as "professional equity capital co-invested with the entrepreneur to fund an early stage (seed, start-up) or expansion venture" [24]. Venture capitalists have developed specific skills and processes that allow them to engage in the early stages of the innovation cycle and manage risks that other investors (e.g. banks) tend to avoid. As opposed to later stage investors, venture capitalists can typically not rely on quantifiable financial data. To compensate for this information asymmetry, venture-capital specific skills are in particular to co-invest with the entrepreneur, to pursue a staged financing approach, to syndicate deals, and to apply portfolio diversification [35,57].

Despite critical comments about the adequacy of the venture capital model for the capital-intensive energy industry [25], "cleantech", including renewable energy and other technologies to increase resource-efficiency, has recently become the third-most important category of venture capital investing. On the one hand, venture capitalists act as innovation agents and thus accomplish a unique task in the diffusion process of renewable energies. On the other hand, their approach to assess an investment opportunity is in principle not different from what later stage investors do: like other investors, venture capitalists weigh the risks and return prospects of an investment opportunity when taking a decision to invest. Typical risks involved in venture financing decisions include technology risk [26-31], people risk [26-29,31-33], market adoption risk and regulatory risk [34]. While the importance of regulatory risk varies across industries, it has been shown to be a relevant factor in clean energy venture capital investing [16], and also for later stage investors such as project developers [6,7] and institutional investors [19].

Research on how venture capitalists perceive regulatory risk and opportunity implied by renewable energy policies shows mixed results. Some policies, such as feed-in tariff schemes that effectively stimulate renewable energy demand, appear to be viewed positively by venture capitalists [16]. However, some venture investors seem to have a reluctant view on regulatory exposure as they find it "harder to manage or even outside their area of influence" [34, p. 73].

\subsection{The influence of worldviews on risk perception and investment decisions}

Research in different financial and non-financial contexts shows that risk perception is moderated by personal attributes such as feelings [36] and worldviews. Worldviews as a theoretical concept go back to the Grid and Group Cultural Theory, which was initially developed by Douglas [37]. The origins of the theory are in anthropological studies: to provide a common framework for comparison of social groups, Douglas suggests in her book Natural Symbols the grid and group analysis. The group dimension measures the degree of cohesion among members of a social group, be it a family, a football team or a cultural group. The grid dimension measures the degree of regulation that governs behaviour of the group members. A plethora of different names for the two dimensions and the resulting worldviews has proliferated (for a review, see [38]). Wildavsky [39] for example labels the dimensions with two fundamental questions for human beings, the group dimension being "Who am I?" and the grid dimension "How should I behave?" Douglas [37] suggests that both dimensions are independently from each other either low or high, leading to four different

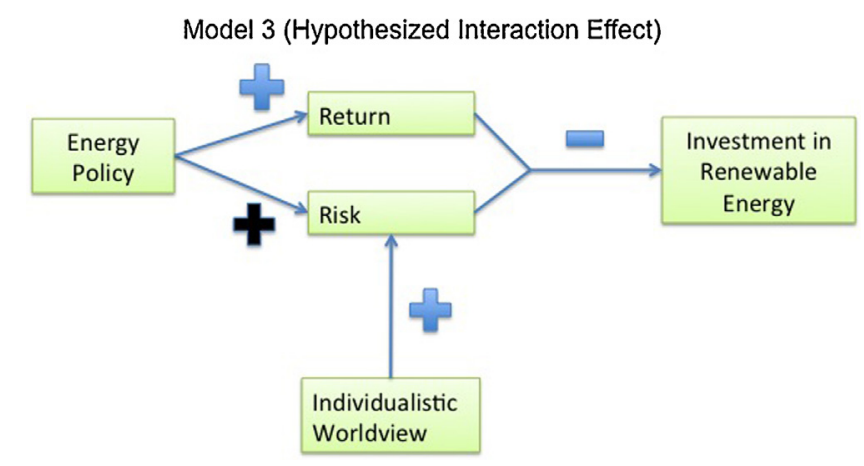

Fig. 3. The moderating influence of worldviews on renewable energy policy effectiveness.

worldviews, defined as a person's "orienting dispositions" [40] for attitude formation "towards the world and its social organization" [41, p. 1430]. A commonly used terminology is the one suggested by Schwarz and Thompson [42] with the four worldviews fatalist, hierarchist, egalitarian and individualist. Empirical research building on cultural theory tends to exclude fatalists, as their deterministic worldview usually prevents them from actively engaging in societal debate (for a review, see [43, p. 5740]). In the context of energy and climate-related social science research, the duality between egalitarian and individualistic worldviews has attracted particular attention.

A study by West et al. [43] examines the influence of worldviews on the perception of renewable energies and renewable energy policies. In six focus group discussions with UK residents, the authors find clear evidence that discussants with an individualistic worldview have very critical views on government intervention in the energy context.

The individualistic worldview relates to a preference for a freemarket society, where "the autonomy of individuals and their resulting freedom to bid and bargain with each other" dominates [42, p. 6]. Lewandowsky et al. [44] find that subscribing to an individualistic worldview and endorsement of free-market economics is widespread among people who reject climate science.

Building upon these insights from literature and previous empirical research we investigate whether venture capitalists' individualistic (or "free-market") worldviews influence their perception of regulatory risk, and consequently their decision to invest in renewable energy firms (cf. Fig. 3).

We test the following hypothesis: the relationship between renewable energy policy and likelihood to invest is moderated by investors' worldviews, in that venture capitalists with an individualistic "free-market" worldview perceive this risk as more severe than investors that do not have strongly individualistic worldviews. Venture capitalists with individualistic worldviews are therefore more likely to avoid investment opportunities characterized by a high level of regulatory risk.

\section{Methodological approach}

\subsection{Choice experiments and adaptive choice-based conjoint analysis}

In order to investigate the influence of regulatory exposure on investor decision-making, we conducted choice experiments with venture capitalists. Choice experiments (typically in form of conjoint analysis) are widely used in marketing research to assess the relative importance of different attributes for consumer decision-making $[61,62]$. In recent years, choice experiments and conjoint analysis have spread from their origin in marketing to a 
Table 1

Sample choice task from web-based survey.

\begin{tabular}{|c|c|c|c|}
\hline Technological maturity & Works in laboratory & Working prototype & Finished product \\
\hline Founder experience & Previous startup founder & Previous executive experience & Graduate student \\
\hline Regulatory exposure & Low & High & Very high \\
\hline Return potential & $\begin{array}{l}10 \times \text { in } 5 \text { years } \\
\bigcirc\end{array}$ & $\begin{array}{l}5 \times \text { in } 5 \text { years } \\
\end{array}$ & $\begin{array}{l}20 \times \text { in } 5 \text { years } \\
\bigcirc\end{array}$ \\
\hline
\end{tabular}

wide range of research fields such as entrepreneurship [63], environmental economics [45-49,64-70], transportation economics [71-73], energy efficiency research [74-76] and, most recently, renewable energy investment decision-making [6,7,59]. Typically, respondents are asked to choose among different alternatives (e.g. products, or in our case, investment opportunities) described along a limited number of attributes. Levels of the attributes vary across the presented alternatives. Choice models assume that the decision maker maximizes utility, and that the utility of any given alternative is the sum of the part-worth utilities of the different attribute levels [50].

We used a specific conjoint method called Adaptive ChoiceBased Conjoint $(A C B C)$ by Sawtooth Software to design the choice experiment in a web-based format. ACBC collects preference data in an interactive mode and through three different sections, which increases the information gathered per respondent. In the first section of the interviewing process (the "build your own" or BYO section) the respondents can compose their most preferred investment opportunity by choosing out of a list of previously defined levels for each of the attributes included in the conjoint design. In the second section (the "screening section") the software generates a series of hypothetical investment opportunities by randomly combining the predefined attribute levels. Respondents have to indicate for each of the presented investment opportunities whether they would invest or not. All selected investment opportunities then enter the third section of the interviewing process (the "choice tournament"). In this last step, the investment options compete against each other in a series of choice tasks until the most preferred alternative is identified. In each choice task, the respondent needs to choose one out of a group of three investment options [51,52].

\subsection{Experimental design}

We applied a symmetric conjoint design with six attributes and four levels per attribute. For a complete list of the attributes and levels included in the conjoint design, see Table 3. In order to make the conjoint experiment as realistic as possible, we included the most important factors influencing venture capital investment decisions $[29,30]$.

One of the attributes was used to operationalize our focal variable, the influence of energy policy on investment decision-making. This attribute, representing a firm's degree of regulatory exposure, had four levels ranging from "very low" to "very high". To ensure that all respondents interpret the attributes and levels in a similar way, we added short mouse-over descriptions of each attribute. In this case, the attribute was described as "presence and extent of regulatory risk". A pre-test with six students and twenty professional venture capitalists confirmed the relevance of the chosen attributes and levels.

All investment options that were presented to the respondents were deals in the clean energy domain. Table 1 shows a sample choice task from the ACBC experiment (choice tournament section).
Table 2

Individualistic worldview statements, 5-point Likert scale ( $1=$ totally agree 5 = totally disagree).

\begin{tabular}{ll}
\hline No. & Statement \\
\hline 1 & $\begin{array}{l}\text { Private enterprise is the best way to solve our } \\
\text { country's economic problems. } \\
\text { If there is no clear need for government, let them stay } \\
\text { out of the way. } \\
\text { We would never invest in a firm that relies on } \\
\text { government subsidies. }\end{array}$ \\
\hline
\end{tabular}

\subsection{Worldview measures}

In order to measure how strongly the venture capitalists adhere to an individualistic worldview, we used a set of three statements (cf. Table 2). Statement 1 is taken from the European Social Survey (ESS). Statements 2 and 3 are formulated based on quotes from in-depth interviews with 23 venture capitalists by Wüstenhagen and Teppo [34]. Whereas statement 2 assesses the general view on the role of government, statement 3 specifically measures the investors' attitude towards government subsidies. Our scale is similar to the four-items scale by Cherry et al. [53] for measurement of individualism, but we used a more VC-specific wording. Similar items have also been used by Lewandowsky et al. [44] based on Heath and Gifford [77]. Answers were given on a 5-point Likert scale with values ranging from 1 (totally agree) to 5 (totally disagree) in order to capture the respondents' agreement/disagreement with the statements. Respondents who agree with the statements in Table 2 are perceived to have a more individualistic "free-market"-oriented worldview than respondents who disagree with the statements.

\subsection{Data collection and sample}

Invitations to participate in the survey were sent out in a mass e-mailing to venture capitalists included in the Thomson ONE Private Equity (formerly VentureXpert) database in March 2010. In total, 176 venture capitalists took part in our survey. The sample was cleaned in several steps for incomplete responses and double entries (44 respondents), respondents from outside of the United States and Europe (16 respondents), and corporate venture capitalists (30 respondents), leading to an extended sample of 86 respondents. ${ }^{2}$ For the analysis in this paper, we report on the choices of those 29 out of the 86 respondents in our extended sample who selected regulatory risk as one of the four most important attributes in the conjoint experiment. The other 57 respondents made use of the option offered by $A C B C$ to exclude attributes that they perceive to be of lower relevance for their investment decision. ${ }^{3}$ While this implies that we cannot generalize from our

\footnotetext{
2 More details on the extended sample can be found in Wuebker et al. [59].

3 The Adaptive Choice Based Conjoint (ACBC) survey allowed respondents to select four out of six attributes for the conjoint interviewing procedure that they felt are of most importance for the decision to invest in a deal. This feature was applied in order to decrease the complexity of the choice tasks. For more details see
} 
final sample to the importance of regulatory risk in the entire population of venture capitalists, it also means that we capture information from those investors who actually take this attribute into account, and we eliminate the noise from other respondents who might just artificially react to the attribute had we included it in the experimental design for the extended sample. Focusing on the subsample also leads to valid results because our research question does not focus on the overall importance of regulatory risk, but on the moderating effects of worldviews. Finally, we carefully checked for differences in sample characteristics and answers to the worldview statements between the final sample of $N=29$ and those respondents who did not select regulatory exposure as a conjoint attribute and did not find any significant results (cf. Appendix).

About $55 \%$ of the respondents in our final sample are based in Europe, $45 \%$ in the United States. The average respondent works in a venture capital firm that has about 22 employees, has been in business for 11 years, manages 3.5 funds and invests on average \$7.15 million per deal. For detailed characteristics of the respondents in our sample please refer to Appendix.

\section{Results}

\subsection{Part-worth utilities of regulatory exposure}

Each respondent in our sample $(N=29)$ had to accomplish on average 36.7 choice tasks (includes BYO, screening and choice tournament), ${ }^{4}$ which results in a data set of 1064 experimental investment decisions. Most of the 29 venture capitalists who chose regulatory exposure as one out of six attributes in the conjoint experiment, also chose the attributes founder experience (28 respondents), technological maturity (18 respondents) and return potential (28 respondents). The attributes deal source and lead investor were chosen by 4 , respectively 9 venture capitalists only. Table 3 displays the average part-worth utilities and standard deviations per attribute level as a result from the hierarchical Bayes estimation procedure $[54,55]$. Using the hierarchical Bayes estimation procedure ensures robust coefficient estimates even in case of scarce information such as in the case of the attributes deal source and lead investor.

The average part-worth utilities indicate the effect of a particular attribute level on the overall utility of the average respondent, i.e. the impact on the hypothetical investment decision. This effect can be positive or negative. One needs to bear in mind that partworth utilities are usually interval data and scaled to an arbitrary constant, thus it is not possible to directly compare utility values of attribute levels across attributes. The utilities in the table are effects-coded zero-centred differentials and sum up to zero within attributes [52].

The results of the conjoint analysis in Table 3 indicate a linear relationship between the attribute levels and part-worth utilities for all attributes, i.e. with increasing risk (e.g. technological risk measured by technological maturity) or return potential the partworth utilities decrease or increase, respectively. In general, this also holds true for the attribute regulatory exposure, so that the likelihood to invest in renewable energy deals decreases with an increase in regulatory exposure. However, this effect is stronger for

\footnotetext{
Sawtooth [60] or http://www.sawtoothsoftware.com/help/issues/ssiweb/online help/index.html?customized_constructed_attri.htm.

4 The exact number of choice tasks per respondent differs due to the adaptive nature of the ACBC interviewing procedure; for more information, please refer to the "Choice experiments and adaptive choice-based conjoint analysis" section of this paper.
}

Table 3

Average part-worth utilities and standard deviations per attribute level.

\begin{tabular}{|c|c|c|}
\hline Attributes and levels & $\begin{array}{l}\text { Average part-worth } \\
\text { utility }\end{array}$ & $\begin{array}{l}\text { Standard } \\
\text { deviation }\end{array}$ \\
\hline \multicolumn{3}{|l|}{ Regulatory exposure } \\
\hline Low & 65.54 & 36.11 \\
\hline Very low & 64.22 & 47.33 \\
\hline High & -35.26 & 40.97 \\
\hline Very high & -94.49 & 46.62 \\
\hline \multicolumn{3}{|l|}{ Return potential } \\
\hline $20 \times$ in 5 years & 53.87 & 34.83 \\
\hline $15 \times$ in 5 years & 25.09 & 14.33 \\
\hline $10 \times$ in 5 years & -10.08 & 19.44 \\
\hline $5 \times$ in 5 years & -68.88 & 34.19 \\
\hline \multicolumn{3}{|l|}{ Technological maturity } \\
\hline In production with customers & 54.15 & 64.11 \\
\hline Finished product & 12.45 & 28.12 \\
\hline Working prototype & -19.76 & 33.89 \\
\hline Works in laboratory & -46.84 & 49.14 \\
\hline \multicolumn{3}{|l|}{ Founder experience } \\
\hline Previous startup founder & 50.73 & 46.35 \\
\hline Previous startup experience & 35.35 & 29.12 \\
\hline Previous executive experience & 11.28 & 40.51 \\
\hline Graduate student & -97.36 & 43.88 \\
\hline \multicolumn{3}{|l|}{ Lead investor } \\
\hline Draper Fisher Jurvetson & 4.03 & 15.04 \\
\hline Kleiner Perkins & 3.19 & 14.87 \\
\hline Insight Capital Partners & -2.66 & 9.25 \\
\hline Khosla Ventures & -4.56 & 12.81 \\
\hline \multicolumn{3}{|l|}{ Deal source } \\
\hline Syndicate partner & 3.32 & 10.15 \\
\hline Personal network & 2.82 & 8.59 \\
\hline Met at venture fair & -2.59 & 6.90 \\
\hline E-mail business plan & -3.56 & 9.33 \\
\hline
\end{tabular}

high levels of regulatory exposure, whereas the average respondent appears to be almost indifferent between low and very low levels of regulatory exposure.

\subsection{The moderating effect of worldviews}

In order to test whether the investors' individualistic worldviews moderate the relationship of regulatory risk and the willingness to invest in renewable energy firms we first calculated the average rating of the three worldview statements in Table 2 per respondent. In a next step we built two distinct groups of respondents, where the first group ("High Individualistic Worldview") on average strongly agreed with all of the three statements (average ratings up to 2.0 from a 5-point Likert scale ranging from $1=$ totally agree to $5=$ totally disagree) and respondents in the second group were indifferent or disagreed with the statements on average indicating a low individualistic worldview.

Fig. 4 shows the average part-worth utilities per level of regulatory exposure for each of the groups. The difference in part-worth utilities per attribute level shows that the group with a high individualistic worldview is significantly more sensitive to regulatory exposure than respondents with a low individualistic worldview. The detailed results further reveal that the group with a low individualistic worldview differentiates less between low levels of regulatory exposure (reversal in the part-worth utilities), which also indicates their willingness to accept some level of regulatory risk. Thus, our results provide evidence that worldviews influence venture capitalists' risk perception related to the exposure of a renewable energy firm to energy policy and support our hypothesis: investors with a less individualistic and thus more positive general attitude towards government intervention in markets perceive higher levels of regulatory exposure as less risky and are more 


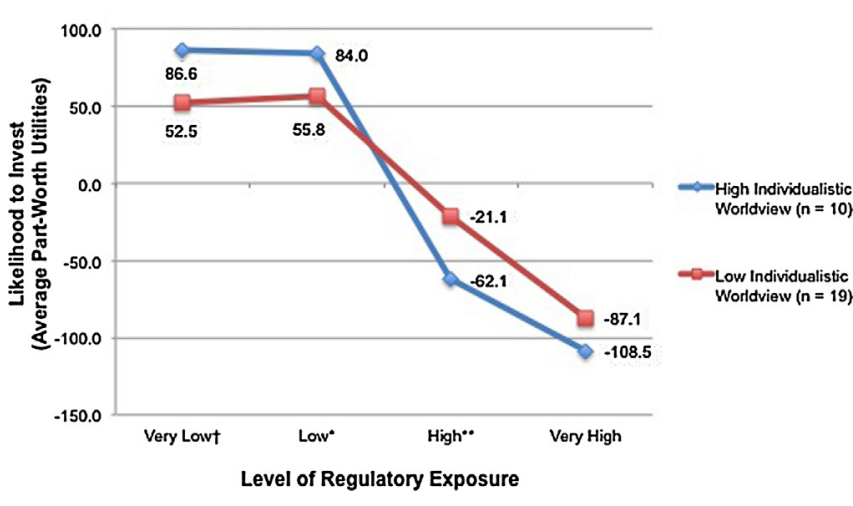

Fig. 4. Average part-worth utilities per level of regulatory exposure and worldview groups. Note: Level of significance indicated for each of the attribute levels relates to the difference in average part-worth utilities between the two groups ( $t$-test, two-sided). ${ }^{\dagger} p<0.10 ;{ }^{*} p<0.05 ;{ }^{* *} p<0.01$.

likely to invest in such renewable energy deals than investors with an individualistic "free-market" attitude.

\section{Limitations and further research}

Our study is an innovative contribution to the emerging research stream on energy policy and renewable energy investment, as it is based on a unique dataset with real investors in a sophisticated experimental setting. Our novel approach combines regulatory risk perception, worldviews and investment decision, and provides new and important insights on the impact of energy policies. However, as any early exploration into an emerging field, our research is characterized by a number of limitations that can provide promising starting points for further research.

First, our results are based on 1064 experimental investment decisions conducted by a final sample of 29 venture capitalists out of a larger group of 86 venture capitalists participating in our overall survey. The reduction in sample size was necessary because this paper has focused on one particular factor in the decision-making process, regulatory exposure, which several of the surveyed venture capitalists deemed not to be among the top four factors they consider when making an investment. We carefully checked for differences between the final sample and the extended sample, and we are therefore confident about the direction of the observed effects, but there are limits to how far we can generalize our findings to the entire venture capital population. Future research using larger samples would be helpful in confirming our findings.

Second, venture capitalists are only a specific subset of the energy investment community $[14,78]$. While they have been shown to be important agents in the financing of innovation, the magnitude of capital flows in other parts of the industry is more significant. Future research should therefore shed light on other investor types, notably corporate investors, pension funds, banks and insurance companies, in order to investigate to what extent venture capitalists' worldviews and perceptions of regulatory risk are indicative of later stage investors in renewable energy.

Third, we investigated venture capitalists' worldviews by surveying their preference for private enterprise over government intervention, using a simplified scale and focusing on individualistic ("free-market") worldviews. Further research could focus on other worldviews and apply established scales to confirm the effects we observed. For example, the scale developed by Dake and Thompson $[40,56]$ for orienting dispositions, which is closely linked to the Grid and Group Cultural Theory. We would caution, however, that applying more comprehensive psychological scales with time-constrained professional investors may pose significant challenges in terms of data collection, resulting in either small samples and/or concerns about self-selection bias. Further research that would develop robust but shorter scales would be particularly valuable.

Fourth, while the use of conjoint analysis enjoys increasing popularity in a wide range of research fields, its application in the context of investment decision-making is still a relatively recent phenomenon. Further research could further validate our findings by comparing stated and revealed preferences, possibly following a case study approach focusing on investor reactions to materializations of policy risk, such as feed-in tariff changes in Spain or the Czech Republic. A particular consideration is that we can only measure the importance of attributes included in our conjoint design. While we used an extensive literature review and qualitative expert interviews to carve out attributes that matter in venture capital decision-making, unobserved factors could influence the results of our analysis and should be investigated in further research. These include, for example, effects of peer pressure or herding behaviour among investors. Also, in an attempt to present respondents a realistic choice task resembling a real investment decision, we devoted only one of the attributes to regulatory risk. This is a simplification in the light of the many shades of regulatory risk, especially when it comes to later stage investment outside of the venture capital area. Further research could include more nuanced measures of regulatory risk, but the trade-off between zooming in on this particular aspect of investment decision-making and still keeping the choice situation as realistic as possible needs to be carefully considered.

Fifth, we investigated the influence of worldviews on perceptions of regulatory risk in the context of investment in clean energy sources such as solar and wind power. As has been shown by Peters and Slovic [41], who found that people with an individualistic worldview are more likely than egalitarians to accept nuclear power, worldviews can also correlate with the perception of technology risk. It would be interesting to combine these aspects in further research on energy investment decision-making, in an attempt to disentangle worldview-induced preferences for certain renewable or non-renewable energy technologies and preferences for certain energy policies. For example, it is interesting to note that the UK government has recently framed what effectively looks like a feed-in tariff for nuclear power as a "contract for differences", framing the policy in a way that appeals to an audience holding an individualistic worldview. Conversely, some of the policy risk aversion expressed by investors scoring high on "free-market" worldviews might spill over to technologies benefiting from feed-in tariffs, such as solar photovoltaics.

Finally, our analysis provides broad support for the idea that "behavioural" factors play a role in investor decision-making, but we would encourage further research to elucidate exactly how and where this plays out in the decision process. This would ultimately contribute to the recent debate in the decision sciences about dual process theories [79] or "thinking fast and slow" [58], painting a nuanced picture of how analytical and intuitive components are combined by real-world decision makers.

\section{Conclusions}

Achieving policy targets for the transition to renewable energy will require substantial private investment. In the analysis presented in this paper, we confirm previous research that suggests policy makers should pay particular attention to (perceived) regulatory risk, rather than just think about providing attractive returns to investors. We empirically demonstrate that venture capital investors exhibit policy risk aversion, in that they tend to avoid 
renewable energy investment opportunities if regulatory exposure is perceived to be high. We also show that investors are comfortable with taking some policy risk, in that there is little difference between their preference between low and very low levels of regulatory exposure. Finally, we highlight that not all investors are equal, and that worldviews play an important moderating role beyond purely "rational" considerations of risk and return. The aversion to policy risk is more pronounced among investors who hold strong individualistic worldviews and thus prefer "free markets" over government intervention.

Our findings have important implications for energy policy. When choosing between various policy instruments to achieve renewable energy targets, policy makers should aim at lowering perceived risk for investors. Furthermore, our findings about the influence of behavioural factors such as worldviews suggest that reducing "objective" levels of risk may be a necessary but not sufficient condition for investor acceptance of policies. Perhaps equally important is that these policies are framed in a way that is consistent with the basic worldviews of key target segments in the investment community. For example, policy-averse venture capital investors might be more likely to accept renewable energy policies that are framed as "mobilizing private capital" rather than as "government intervention", and they may prefer "incentives" over "subsidies".

\section{Acknowledgements}

The authors acknowledge funding from the Swiss National Science Foundation, project no. 100014_125044. We acknowledge Robert Wuebker's contributions to the empirical design of the choice experiments. We appreciate comments received by reviewers and participants of the Rent XXV - Research in Entrepreneurship and Small Business Conference 2011, the IAREP/SABE/ICABEEP 2011 Conference, the Academy of Management Conference 2013 and the Swiss Society of Economics and Statistics Annual Conference 2013. Our thanks also go to the editor and two anonymous reviewers of Energy Research and Social Science. All remaining errors are our own.

\section{Appendix.}

See Table A.1.

Table A.1

Descriptive statistics.

\begin{tabular}{|c|c|c|c|c|c|c|c|c|c|c|}
\hline \multirow[t]{3}{*}{ Sample characteristics } & & & & & \multicolumn{5}{|c|}{ For comparison (cf. Section 3.4) } & \multirow{3}{*}{$\begin{array}{l}\text { Extended sample } \\
(N=86) \\
\text { Mean/\% }\end{array}$} \\
\hline & \multicolumn{4}{|c|}{ Final sample $(N=29)$} & \multicolumn{4}{|c|}{$\begin{array}{l}\text { Respondents who did not select } \\
\text { attribute "regulatory risk" }(N=57)\end{array}$} & \multirow[t]{2}{*}{$\begin{array}{l}\text { Test of difference ( } p \text {-value } \\
\text { of } t \text {-test or } \chi^{2} \text {-test) }\end{array}$} & \\
\hline & $N$ & & Mean & SD & $N$ & & Mean & SD & & \\
\hline \multicolumn{11}{|l|}{ Firm and fund information } \\
\hline Firm location & & & & & & & & & 0.321 & \\
\hline Europe & 16 & $(55 \%)$ & & & 25 & $(44 \%)$ & & & & $48 \%$ \\
\hline United States & 13 & $(45 \%)$ & & & 32 & $(56 \%)$ & & & & $52 \%$ \\
\hline $\begin{array}{l}\text { Firm size (number of } \\
\text { employees) }\end{array}$ & 29 & & 21.86 & 32.63 & 57 & & 16.05 & 19.70 & 0.307 & 18.01 \\
\hline Firm age (years) & 29 & & 11.03 & 7.83 & 57 & & 13.63 & 8.47 & 0.172 & 12.76 \\
\hline Number of funds $s^{\mathrm{a}}$ & 28 & & 3.50 & 3.44 & 57 & & 2.60 & 1.82 & 0.201 & 2.89 \\
\hline Deal size (in millions \$) & 29 & & 7.15 & 12.80 & 57 & & 7.88 & 12.90 & 0.806 & 7.63 \\
\hline \multicolumn{11}{|l|}{ Investor information } \\
\hline Investor age (years) & 29 & & 42.48 & 12.56 & 57 & & 43.82 & 10.56 & 0.603 & 43.37 \\
\hline VC industry affiliation (years) & 29 & & 8.76 & 7.52 & 57 & & 9.12 & 7.58 & 0.833 & 9.00 \\
\hline $\begin{array}{l}\text { VC investment experience } \\
\text { (years) }\end{array}$ & 29 & & 7.00 & 6.93 & 57 & & 7.65 & 7.06 & 0.686 & 7.43 \\
\hline Number of boards & 29 & & 7.28 & 7.29 & 57 & & 8.16 & 10.56 & 0.688 & 7.86 \\
\hline Position in firm & & & & & & & & & 0.127 & \\
\hline Managing director & 12 & $(41 \%)$ & & & 16 & $(28 \%)$ & & & & $33 \%$ \\
\hline General partner & 5 & $(17 \%)$ & & & 7 & $(12 \%)$ & & & & $14 \%$ \\
\hline Partner & 2 & $(7 \%)$ & & & 15 & $(26 \%)$ & & & & $20 \%$ \\
\hline Analyst & 8 & $(28 \%)$ & & & 10 & $(18 \%)$ & & & & $21 \%$ \\
\hline Other & 2 & $(7 \%)$ & & & 9 & $(16 \%)$ & & & & $13 \%$ \\
\hline \multicolumn{11}{|c|}{ Industry domain experience (years) ${ }^{\mathrm{b}}$} \\
\hline Clean energy & 17 & & 6.12 & 7.47 & 28 & & 4.46 & 4.65 & 0.364 & 5.09 \\
\hline Biotechnology & 13 & & 6.77 & 6.57 & 25 & & 7.88 & 7.82 & 0.664 & 7.50 \\
\hline ICT & 14 & & 7.21 & 7.51 & 36 & & 9.33 & 7.83 & 0.389 & 8.74 \\
\hline Consumer related & 15 & & 8.73 & 7.26 & 29 & & 6.62 & 6.54 & 0.333 & 7.34 \\
\hline Conventional energy & 8 & & 10.63 & 8.12 & 11 & & 6.91 & 6.01 & 0.266 & 8.47 \\
\hline Medical/health & 18 & & 5.61 & 5.77 & 33 & & 7.45 & 7.72 & 0.380 & 6.80 \\
\hline \multicolumn{11}{|l|}{ Worldview statements } \\
\hline $\begin{array}{l}\text { Private enterprise is the best } \\
\text { way to solve our country's } \\
\text { economic problems }\end{array}$ & 29 & & 2.03 & 0.87 & 56 & & 2.11 & 1.06 & 0.751 & 2.08 \\
\hline $\begin{array}{l}\text { If there is no clear need for } \\
\text { government, let them stay } \\
\text { out of the way. }\end{array}$ & 29 & & 2.69 & 1.31 & 56 & & 2.82 & 1.44 & 0.682 & 2.78 \\
\hline $\begin{array}{l}\text { We would never invest in a } \\
\text { firm that relies on } \\
\text { government subsidies. }\end{array}$ & 29 & & 2.45 & 1.43 & 55 & & 2.75 & 1.22 & 0.320 & 2.64 \\
\hline
\end{tabular}

a One respondent did not indicate the number of funds.

b Multiple answers possible. 


\section{References}

[1] Frankfurt School-UNEP Centre/BNEF. 2014. Global trends in renewable energy investment 2014, http://www.fs-unep-centre.org (Frankfurt am Main).

[2] IEA. World energy outlook 2012. Paris: IEA; 2012.

[3] Hamilton K. Unlocking finance for clean energy: the need for 'investment grade' policy. Chatham House; 2009.

[4] Holburn GLF. Assessing and managing regulatory risk in renewable energy: contrasts between Canada and the United States. Energy Policy 2012;45:654-65.

[5] Mitchell C, Bauknecht D, Connor P. Effectiveness through risk reduction: a comparison of the renewable obligation in England and Wales and the feed-in system in Germany. Energy Policy 2006;34(3):297-305.

[6] Lüthi S, Wüstenhagen R. The price of policy risk-empirical insights from choice experiments with European photovoltaic project developers. Energy Econ 2012;34(4):1001-11.

[7] Lüthi S, Prässler T. Analyzing policy support instruments and regulatory risk factors for wind energy deployment-a developer's perspective. Energy Policy 2011;39:4876-92.

[8] Dinica V. Support systems for the diffusion of renewable energy technologies-an investor perspective. Energy Policy 2006;34:461-80.

[9] Johnston A, Kavali A, Neuhoff K. Take-or-pay contracts for renewables deployment. Energy Policy 2008;36:2481-503.

[10] Barradale MJ. Impact of public policy uncertainty on renewable energy investment: wind power and the production tax credit. Energy Policy 2010;38:7698-709.

[11] Simon HA. A behavioral model of rational choice. Quart J Econ 1955;69(1):99-118.

[12] Unruh GC. Understanding carbon lock-in. Energy Policy 2000;28:817-30.

[13] Wilson C, Dolatabadi H. Models of decision making and residential energy use. Ann Rev Environ Resour 2007;32:169-203.

[14] Wüstenhagen R, Menichetti E. Strategic choices for renewable energy investment: conceptual framework and opportunities for further research. Energy Policy 2012;40:1-10

[15] Sunstein CR, Reisch L. Automatically green: behavioral economics and environmental protection. Harv Environ Law Rev 2014;38(1):127-58.

[16] Bürer MJ, Wüstenhagen R. Which renewable energy policy is a venture capitalist's best friend? Empirical evidence from a survey of international clean energy investors. Energy Policy 2009;37(12):4997-5006.

[17] Lüthi S. Effective deployment of photovoltaics in the Mediterranean countries: balancing policy risk and return. Sol Energy 2010;84:1059-71

[18] Langniss O. Financing renewable energy systems. London: Kiel; 1999.

[19] Chassot S, Wüstenhagen R. Implicit cognition and renewable energy investments: an empirical analysis of differences between financial and strategic investors. Final report. Berne: Swiss Federal Office of Energy; 2013 [contract no. 8100087].

[20] Baratoff MC, Black I, Burgess B, Felt JE, Garratt M, Guenther C. Renewable power, policy, and the cost of capital: improving capital market efficiency to support renewable power generation projects prepared for UNEP/BASE sustainable energy finance initiative. Ann Arbor, MI: University of Michigan, Erb Institute for Global Sustainable Enterprise; 2007.

[21] de Jager D, Rathmann M. Policy instrument design to reduce financing costs in renewable energy technology projects by order of IEA RETD implement agreement. Utrecht: Ecofys; 2008.

[22] Baum JAC, Silverman BS. Picking winners or building them? Alliance, intellectual, and human capital as selection criteria in venture financing and performance of biotechnology startups. J Bus Venturing 2004;19(3):411-36.

[23] Florida R, Smith DF. Venture capital, innovation, and economic development. Econ Develop Quart 1990;4(4):345-60.

[24] EVCA. Research and Data-Glossary. Retrieved from http://www.evca.eu/ knowledgecenter/glossary.aspx?id=982 [07.01.13].

[25] Kenney M. Venture capital investment in the Greentech industries: a provocative essay. In: Wüstenhagen R, Wuebker R, editors. Handbook of research on energy entrepreneurship. Edward Elgar Publishing: Cheltenham, UK/Lyme, USA; 2011. p. 214-28.

[26] DeSarbo W, MacMillan IC, Day DL. Criteria for corporate venturing: importance assigned by managers. J Bus Venturing 1987;2(4):329-50.

[27] MacMillan IC. Criteria used by venture capitalists to evaluate new venture proposals. J Bus Venturing 1985;1:119-28.

[28] MacMillan IC, Zemann L, Subba Narasimha PN. Criteria distinguishing successful from unsuccessful ventures in the venture screening process. J Bus Venturing 1987;2:123-37.

[29] Petty JS, Gruber M. In pursuit of the real deal: a longitudinal study of VC decision making. J Bus Venturing 2011;26(2):172-88.

[30] Tyebjee TT, Bruno AV. A model of venture capitalist investment activity. Manage Sci 1984;30(9):1051-66.

[31] Zider B. How venture capital works. Harv Bus Rev 1998;76(6):131-40.

[32] Franke N, Gruber M, Harhoff D, Henkel J. What you are is what you like-similarity biases in venture capitalists' evaluations of start-up teams. J Bus Venturing 2006;21:802-26.

[33] Franke N, Gruber M, Harhoff D, Henkel J. Venture capitalists' evaluations of start-up teams: trade-offs, knock-out criteria, and the impact of VC experience. Entrepreneurship Theory Practice 2008;32(3):459-83.
[34] Wüstenhagen R, Teppo T. Do venture capitalists really invest in good industries? Risk-return perceptions and path dependence in the emerging European energy VC market. Int J Technol Manage 2006;34(2):63-87.

[35] Wright M, Lockett A. The structure and management of alliances: syndication in the venture capital industry. J Manage Stud 2003;40(8):2073-102.

[36] Loewenstein GF, Weber EU, Hsee CK, Welch N. Risk as feelings. Psychol Bul 2001;127(2):267-86.

[37] Douglas M. Natural symbols, explorations in cosmology. New York: Vintage Books; 1970

[38] Mamadouh V. Grid-group cultural theory: an introduction. GeoJourna 1999;47:395-409.

[39] Wildavsky A. Choosing preferences by constructing institutions: a cultural theory of preference formation. Am Polit Sci Rev 1987;81(1):3-22.

[40] Dake K. Orienting dispositions in the perception of risk: an analysis of contemporary worldviews and cultural biases. J Cross-Cult Psycho $1991 ; 22(61): 61-82$

[41] Peters E, Slovic P. The role of affect and worldviews as orienting dispositions in the perception and acceptance of nuclear power. J Appl Soc Psychol 1996;26(16):1427-53.

[42] Schwarz M, Thompson M. Divided we stand: redefining politics, technology and social choice. Hemel Hempstead: Harvester Wheatsheaf; 1990.

[43] West J, Bailey I, Winter M. Renewable energy policy and public perceptions of renewable energy: a cultural theory approach. Energy Policy 2010;38:5739-48.

[44] Lewandowsky S, Oberauer K, Gignac GE. NASA faked the moon landing-therefore (climate) science is a hoax: an anatomy of the motivated rejection of science. Psychol Sci 2013.

[45] Álvarez-Farizo B, Hanley N. Using conjoint analysis to quantify public preferences over the environmental impacts of wind farms. An example from Spain. Energy Policy 2002;30(2):107-16.

[46] Ladenburg J, Dubgaard A. Willingness to pay for reduced visual disamenities from offshore wind farms in Denmark. Energy Policy 2007;35(8):4059-71.

[47] Birol E, Koundouri P, Kountoyris Y. Applications of the choice experimen method in Europe: a review. In: Birol E, Koundouri P, editors. Choice experiments informing environmental policy: a European perspective. Edward Elgar Publishing: Cheltenham, UK/Lyme, USA; 2008.

[48] Friebe CA, von Flotow P, Täube FA. Exploring the link between products and service in low-income markets-evidence from solar home systems. Energy Policy 2013;52:760-9.

[49] Kaenzig J, Heinzle S, Wüstenhagen R. Whatever the customer wants, the customer gets? Exploring the gap between consumer preferences and default electricity products in Germany. Energy Policy 2013;53:311-22.

[50] Backhaus K, Erichson B, Plinke W, Weiber R. Multivariate Analysemethoden eine anwendungsorientierte Einführung, 13. Berlin: Springer-Verlag; 2010

[51] Johnson RM, Orme BK. A new approach to adaptive CBC. Sawtooth Software research paper series; 2007.

[52] Orme BK. Getting started with conjoint analysis: strategies for product design and pricing research. Madison, WI: Research Publishers; 2010.

[53] Cherry T, García L, Kallbekken JH, Torvanger SA. The development and deployment of low-carbon energy technologies: the role of economic interests and cultural worldviews on public support. Energy Policy 2014;68:562-6.

[54] Johnson RM. Understanding HB: an intuitive approach. Sawtooth Software research paper series; 2000 .

[55] Sawtooth Software. The CBC/HB system for hierarchical Bayes: version 5.0 technical paper; 2009.

[56] Dake K, Thompson M. The meanings of sustainable development: household strategies for managing needs and resources. In: Wright SD, Dietz T, Borden R, Young G, Guagnanp G, editors. Human ecology: crossing boundaries. Fort Collins, CO: The Society for Human Ecology; 1993.

[57] Gompers P. Optimal investment, monitoring, and the staging of venture capital. J Finan 1995;50(5):1461-89.

[58] Kahneman D. Thinking, fast and slow. London: Allen Lane; 2011.

[59] Wuebker, R., Hampl, N., Wüstenhagen, R. The strength of strong ties in an emerging industry: experimental evidence of the effects of status hierarchies and personal ties in venture capitalist decision-making. Strat Entrepreneurship J 2014 [forthcoming].

[60] Sawtooth Software. The adaptive choice-based conjoint (ACBC) technica paper; 2009

[61] Green PE, Srinivasan V. Conjoint analysis in marketing: new developments with implications for research and practice. J Market 1990;54:3-19.

[62] Orme B. Which conjoint method should I use? Research paper series Sequim, WA: Sawtooth Software Inc.; 2007

[63] Lohrke FT, Holloway BB, Woolley TW. Conjoint analysis in entrepreneurship research: a review and research agenda. Organ Res Methods 2010;13(1): $16-30$.

[64] Ahn J, Jeong G, Kim Y. A forecast of household ownership and use of alternative fuel vehicles: a multiple discrete-continuous choice approach. Energy Econ 2008;30:2091-104.

[65] Boxall PC, Adamowicz WL, Swait J, Williams M, Louviere J. A comparison of stated preference methods for environmental valuation. Ecol Econ 1996; 18:243-53.

[66] Casey JF, Kahn JR, Rivas AAF. Willingness to accept compensation for the environmental risks of oil transport on the Amazon: a choice modeling experiment. Ecol Econ 2008;67:552-9. 
[67] Chattopadhyay S. The random expenditure function approach to welfare in RUM: the case of hazardous waste clean-up. Resour Energy Econ 2009;31:58-74

[68] Farber S, Griner B. Valuing watershed quality improvements using conjoint analysis. Ecol Econ 2000;34:63-76.

[69] Glenn H, Wattage P, Mardle S, Rensburg TV, Grehan A, Foley N. Marine protected areas-substantiating their worth. Mar Policy 2010;34:421-30.

[70] Roe B, Boyle KJ, Teisl MF. Using conjoint analysis to derive estimates of compensating variation. J Environ Econ Manage 1996;31:145-59.

[71] Hensher DA. Stated preferences analysis of travel choices-the state of practice. Transportation 1994:21:107-33.

[72] Hensher DA. Hypothetical bias, choice experiments and willingness to pay. Transport Res B: Methodol 2010;44:735-52.

[73] Train K, Wilson WW. Estimation on stated-preference experiments constructed from revealed-preference choices. Transport Res B: Methodo 2008;42:191-203.
[74] Banfi S, Farsi M, Filippini M, Jakob M. Willingness to pay for energy-saving measures in residential buildings. Energy Econ 2008;30:503-16.

[75] Moxnes E. Estimating customer utility of energy efficiency standards for refrigerators. J Econ Psychol 2004;25:707-24

[76] Poortinga W, Steg L, Vlek C, Wiersma G. Household preferences for energysaving measures: a conjoint analysis. J Econ Psychol 2003;24:49-64.

[77] Heath Y, Gifford R. Free-market ideology and environmental degradation: the case of belief in global climate change. Environ Behav 2006:38:48-71.

[78] Bergek A, Mignon I, Sundberg G. Who invests in renewable electricity production? Empirical evidence and suggestions for further research. Energy Policy 2013;56:568-81.

[79] Gawronski B, Creighton LA. Dual Process Theories. In: Carlston DE, editor. The Oxford Handbook of Social Cognition. New York NY: Oxford University Press; 2013. p. 282-312 